\title{
SENSACYJNE ODKRYCIE TEKSTU HEBRAJSKIEGO
}

W dniu 9 marca 1960 r. Izraelska Agencja Prasowa oraz prasa światowa podały wiadomość o sensacyjnym odkryciu fragmentów listu hebrajskiego pisanego na ostrakach (skorupach dzbanu) w pobliżu miejscowości Rison Lesion w styczniu 1960 r. Jest to najstarszy list hebrajski z dotychczas nam znanych i jest o wiele wcześniejszy od znanych nam listów z Lachisz (początek VI w. przed Chr.).

List ten, składający się z. 14 linii pisma atramentowego znaleziony został przez ekspedycję archeologiczną Departamentu Starożytności w czasie przeprowadzanych prac wykopaliskowych wokół starożytnego fortu położonego na płołudnie ad Jabne Jam. Zdaniem archeolo gów list ten pochodzi z drugiej połowy VII w. przed Chr. Treścią tego listu jest apel pewnego wieśniaka skierowany do swego księcia, by ten spowodował oddanie mu płaszcza, który, zgodnie ze zwyczajem biblijnym, ulegał konfiskacie złym dłużnikom. Wieśniak zaprzecza w liście jakoby on był dłużnikiem.

Szczegóły tego listu, jak również innych zdobyczy archeologicznych podane zostały do wiadomości na konferencji prasowej w Jerozolimie w dniu 9. 03. br. przez Józefa Nabeh, inspektora Departamentu Starożytności dla Obszaru Centralnego, który stał na czele ekspedycji archeologicznej.

Aczkolwiek większość listu jest dobrze zachowana, to jednak z pełnym powodzeniem zdołano - jak dotąd - odcyfrować i odczytać tylko siedem linii. Nazwisko księcia, do którego zwraca się ów wieśniak jest nam bliżej nieznane, lecz wiadomym jest, że był on współczesnym króla judzkiego Jozjasza (638-609 przed Chr.) wzmiankowanego w 2 Księdze Kronik. Książę ten zamieszkiwał prawdopodobnie fort, na ślady którego natknęła się wspomniana ekspedycja archeologiczna.

$\mathrm{Z}$ treści listu wynika dalej, że wieśniak ukończył właśnie zbieranie plonów, prawdopodobnie w okolicy fortu: List swój rozpoczyna wieśniak od zwyczajowej formuły sakralnej „Niechaj pan i książe raczy posiuchać stowa stugi swego“. A dalej pisze ,...i on wzią płaszcz stugi tuego, gdy ja kończyłem zbieranie plonu. (?) wziąt płaszcz twego stugi i wszyscy" - moi bracia zaświadczyć moga na moja korzyść, którzy wraz ze mna zbierali plon $w$... Moi bracia bẹda wiernie świadczyć na moja korzyść (amen) Jestem niewinny (jakiegokolwiek przęstępstwa) ... mój píaszcz i ja chcemy spełnić księcia ... “.

Zwyczaj biblijny konfiskowania płaszcza dłużnikowi udokumentowany jest $\mathrm{w}$ Biblii na kilkunastu miejscach łącznie $\mathrm{z}$ relacją księgi 
Wyjścia (22, 25-27), Powtórzonego Prawa i Przypowieści. Konfiskata płaszcza była dlatego tak bolesną dla każdego, iż stanowił on nakrycie w czasie snu.

Wprawne pismo listu $z$ jednej strony, a $z$ drugiej niezgrabny język każą, zdaniem J. Nabeh, przypuszczać, że wieśniak list ten dyktował jakiemuś pisarzowi dworskiemu, strzegącemu bramy wejściowej do fortu. Istnieje także przypuszczenie, iż wieśniak usiłował uzyskać osobistą audiencję u księcia, która jednak została mu odmówiona. Niewiadomo nam jakie kroki poczynił książę w tej sprawie, lecz list znaleziony został w miejscu, gdzie znajdowała się wartownia fortu, tuż opodal bramy wejściowej. J. Nabeh oświadczył, że analiza porównawcza tak skorup dzbanu, jak również pisma użytego $\mathrm{w}$ liście z pismem listów z Lachisz, dostarcza dowodów na to, by powstanie tego listu można bylo odnieść od drugiej połowy VIL w. Prace nad odcyfrowaniem i odczytaniem dalszej treści listu trwają. Trudnośé szczególną stwarza uczonym odezytanie jednego słowa, nie zachodzącego ani w Bibiii ani też innych znanych nam dotąd dokumentach hebrajskich.

Znaleziony list posiada również szczególne znaczenie dla historii biblijnej, gdyż ukazuje, iż pobożny król judzki Jozjasz posiadał wỉadzę zwierzchnią nad wspomnianym w liście księciem. Jozjasz był suwerenem wybrzeża morskiego, będącego poprzednio w posiadaniu prowincji asyryjskiej Ašdod, a król judzki obszar ten zaludnił wieśniakami judzkimi. Dotąd wiadomym było, iż Jozjasz podbił północną część Izraela i część Negebu, obecnie zaś dodać możemy, iż korzystając z upadku imperium. asyryjskiego, hegemonię swą prawdopodobnie poszerzył także na obszar wybrzeża morskiego, jak również fort znajdujący się na tym obszarze.

Gdy chodzi o sam fort, to stanowi on strukture jednolitą. Dotąd nie wiadomo jednak kto był budowniczym tegoż fortu. Wydaje się być bardzo prawdopodobnym, że w okresie późniejszym fort ten zamieszkiwany był przez Fenicjan, którzy osiedlili się wzdłuż wschodniej części wybrzeża Morza Sródziemnego. Lecz twierdzy tej jako takiej nie wykorzystywali.

List wieśniaka znaleziony został na głębokości $15 \mathrm{~cm}$ poniżej powierzchni. Na tym samym obszarze ekspedycja archelogiczna natrafiła na jeszcze trzy inne inskrypcje. Jedna $z$ nich wyryta jest na grzbiecie dzbanu i rozpoczyna się od słów „Należacy do Hašabjahu, syma Ja..." Dwie pozostałe inskrypcje pisane są atramentem na ostrakach i są bardzo trudne do odcyfrowania. Prace wykopaliskowe podjęte przez Departament Starożytności i Izraelskie Towarzystwo Badań (Israel Exploration Society) rozpoczęte zostały 10 stycznia $1960 \mathrm{r}$. i trwały trzy tygodnie. Spodziewane są dalsze prace $\mathrm{w}$ okresie letnim br., które mogą nauce odsłohić jeszcze niejeden szczegół, pozostający do dziś tajemnicą ziemi palestyńskiej.

Kraków

Ks. LUDWIK STEFANIAK CM. 